\title{
DESKRIPSI KESALAHAN SISWA MEMECAHKAN SOAL BERBENTUK CERITA PADA MATERI SEGIEMPAT
}

\author{
Meli Susanti ${ }^{1}$, Luvy Sylviana Zanthy ${ }^{2}$, Nelly Fitriani ${ }^{3}$ \\ 1,2,3 IKIP Siliwangi, Jl. Terusan Jenderal Sudirman, Cimahi, Indonesia \\ Email: meli16510200@gmail.com
}

\begin{abstract}
The question of the story on the quadrilateral material is a problem that is often encountered by students, but the ability of students to solve rectangular material problems is still a lot of mistakes and mistakes. The results showed that the error rate of student answers was still very high. Errors occur in students' understanding in understanding the problems contained in the problems, so students experience errors in answering questions by not writing down the information contained in the questions, mistakenly using formulas, mistaken when operating numbers and not completing with answer conclusions. The research aims to analyze and describe students' mistakes in answering quadrilateral story questions. Evaluate learning activities by looking at the results of students' answers. The method used in this research is descriptive qualitative method. The research subjects of eighth grade students at Budi Luhur IT Junior High School Cimahi were 17 students with varied abilities, data collection techniques with four question essay tests and direct interviews with students.
\end{abstract}

Keywords: Mistakes, quadrilateral, story matter

\section{ABSTRAK}

Soal cerita pada materi segiempat merupakan soal yang sering ditemui oleh siswa, namun kemampuan siswa dalam menyelesaikan soal materi segiempat masih banyak melakukan kesalahan dan kekeliruan. Hasil penelitian menunjukkan bahwa tingkat kesalahan jawaban siswa masih sangat tinggi. Kesalahan terjadi pada pemahaman siswa dalam memahami permasalahan yang terdapat pada soal, sehingga siswa mengalami kekeliruan dalam menjawab soal dengan tidak menuliskan informasi yang terdapat pada soal, keliru menggunakan rumus, keliru pada saat mengoperasikan bilangan dan tidak melengkapi dengan kesimpulan jawaban. Penelitian bertujuan untuk menganalisis dan mendeskripsikan kesalahan siswa dalam menjawab soal cerita materi segiempat. Evaluasi kegiatan belajar dengan cara melihat hasil jawaban siswa. Metode yang digunakan dalam penelitian yaitu metode deskriptif kualitatif. Subjek penelitian adalah siswa kelas VIII di SMP IT Budi Luhur Kota Cimahi sebanyak 17 siswa dengan kemampuan bervariasi. Teknik pengambilan data dengan soal uraian sebanyak empat buah dan wawancara langsung dengan siswa.

Kata kunci: Kesalahan, materi segiempat, soal cerita

Dikirim: 07 Januari 2020; Diterima: 17 Februari 2020; Dipublikasikan: 30 Maret 2020

Cara sitasi: Susanti, M., Zanthy, L. S., \& Fitriani, N. (2020). Deskripsi kesalahan siswa memecahkan soal berbentuk cerita pada materi segiempat. Teorema: Teori dan Riset Matematika, 5(1), 77-88. 


\section{PENDAHULUAN}

Pendidikan merupakan usaha sadar untuk menyiapkan generasi yang siap dalam meneruskan berbagai perubahan yang baik dimasa yang akan datang. Menurut (Sholekah,et.al, 2017) pendidikan merupakan wadah bagi peserta didik untuk mengembangkan berbagai kemampuan dan potensi yang dimiliki oleh diri individu. Karena setiap perubahan zaman dan teknologi pendidikan itu sangat diperlukan untuk mampu beradaptasi dengan berbagai perubahan. Pendidikan merupakan salah satu usaha manusia untuk mengubah dan membina kepribadian yang melandaskan dengan nilai-nilai baik di dalam masyarakat maupun kebudayaan melalui proses pendidikan karena dengan pendidikan manusia akan memperoleh ilmu pengetahuan untuk bekal mereka hidup (Suraji, et.al, 2017). Salah satu pendidikan yang perlu diperoleh siswa dan masyarakat umum adalah pendidikan matematika, karena matematika sering digunakan dalam kehidupan manusia.

Matematika merupakan salah satu pelajaran yang penting, karena selain dituntut untuk melatih kemampuan berpikir seseorang, banyak masalah dalam kehidupan yang dapat disajikan dalam model matematika, sehingga setiap jenjang pendidikan diwajibkan untuk menempuh pelajaran matematika. Menurut Zanthy (2016) melalui belajar matematika seseorang akan terbiasa berpikir terstuktur, logis, analitis, ilmiah dan sistematis. Matematika adalah ilmu yang universal yang mendasari perkembangan teknologi modern, memiliki peranan penting di berbagai disiplin ilmu dan memajukan daya pikir manusia. Menurut Permendiknas No 22 bahwa matematika diperlukan dalam bidang teknologi yang dilandasi oleh perkembangan matematika di bidang aljabar, analisis, teori peluang dan matematika diskrit (Yuharsono, 2018).

Menurut Martini dan Jamaris bahwa matematika merupakan bidang studi yang perlu dipelajari, karena hakikat matematika adalah pemahaman terhadap pola perubahan yang terjadi di dunia nyata dan di dalam pikiran manusia serta keterkaitan pola-pola tersebut secara holistik (Dwidarti, et. al, 2019). Matematika merupakan ilmu yang sering digunakan dalam kehidan sehari-hari, seperti pengukuran bidang, transaksi jual beli dan yang lainnya. Pendapat tersebut diperkuat oleh Abdurahman (Dwidarti, et. al, 2019) yang menyatakan bahwa mempelajari matematika itu dapat membantu dalam memecahkan masalah kehidupan sehari-hari, menjadikan sarana untuk mengenal pola-pola dan generalisasi hubungan dan mengasah pemikiran sesorang. Sehingga mempelajari matematika itu penting bagi siswa khususnya dan bagi masyarakat pada umumnya.

Pentingnya belajar matematika dikuatkan oleh Cockroft (Martini, et. al, 2018) antara lain: (1) dalam kehidupan sehari-hari sering digunakan; (2) semua bidang studi memerlukan keterampilan matematika yang sesuai dengan bidangnya; (3) sarana komunikasi; (4) digunakan untuk menyajikan informasi dengan berbagai cara; dan (5) meningkatkan kepuasan terhadap usaha. Selain itu pentingnya belajar matematika karena matematika digunakan secara luas dalam segala bidang kehidupan manusia. Menurut Fauzi, et.al, (2019) dengan belajar matematika beberapa kemampuan siswa akan terlatih seperti kemampuan berpikir logis, analitis, sistematis, kritis, kreatif dan mengasah kemampuan menyelsaikan masalah dan bekerjasama (Evi, 2011).

Walaupun matematika sangat penting untuk dipelajari dan dikuasai siswa, namun tidak dapat dipungkiri bahwa matematika memiliki sifat abstrak yang menjadi salah satu sebab matematika sulit untuk dipahami siswa (Yenni \& Sukmawati, 2019). Ironisnya di kalangan siswa bahwa mata pelajaran matematika merupakan salah satu mata pelajaran yang kurang disenangi, motivasi mereka dalam belajar matematika masih rendah sehingga penguasaan siswa terhadap penyelesaian dan pemahaman persoalan matematika sangat kurang dan sulit untuk memfokuskan siswa dalam proses pembelajaran (Hanifah, et.al, 2019). Oleh karena itu, siswa perlu diberikan pemahaman tentang pentingnya arti belajar, manfaat belajar, bagaimana mencapainya, sehingga siswa akan mengerti tentang kegunaan materi pelajaran matematika dalam kehidupannya (Zakiah, et.al, 2019).

Salah satu kesulitan siswa dalam menyelesaikan persoalan matematika yaitu permasalahan matematika yang berbentuk soal cerita. Menurut Abidin (Dwidarti, et. al, 2019) bahwa soal cerita merupakan soal yang disajikan dalam bentuk cerita pendek yang diambil dari cerita kehidupan sehari-hari, ataupun 
masalah lainnya yang siswa pahami dan perlu siswa ubah kedalam pemodelan matematika. Salah satu materi yang kurang siswa pahami yaitu mengenai persoalan pada soal cerita materi segiempat.

Kesulitan siswa SMP kelas VIII dalam menyelesaikan soal cerita segiempat disebabkan oleh rendahnya kemampuan dan pemaham konsep matematis. Menurut Santrock (Yulia, 2019) pemahaman konsep merupakan kunci dari pembelajaran, karena tanpa memahami konsep siswa tidak akan mampu menyelesaikan persoalan matematika biasa ataupun yang berupa soal cerita. Selain itu menurut Kilpatrick, Swafford \& Findell (Yulia, 2019) bahwa pemahaman konsep matematis adalah salah satu dari lima kemampuan atau kecakapan matematis yang harus dikuasai siswa dalam pembelajaran matematika, karena dengan memahami konsep siswa akan mudah memahami permasalahan dan mampu menyelesaikannya sesuai aturan dan benar jawabannya. Salah satu penyebabnya adalah kesalahan siswa dalam menyelsaikan permasalahan soal cerita materi segiempat dikarenakan pemahaman konsep yang kurang. Selanjutnya menurut Widyaningrum (2016) untuk dapat menyelesaikan soal cerita dengan benar diperlukan kemampuan awal seperti kemampuan membaca, menentukan apa yang diketahui dan ditanyakan dalam soal, mampu mengubah ke bentuk model matematika, kemampuan menghitung serta mampu menuliskan jawaban dengan benar. Menurut Djamarah (Nadjib, 2014) faktor yang mempengaruhi siswa melakukan kesalahan dalam menyelesaikan permasalahan meteri segiempat umumnya dipengaruhi oleh dua faktor, antara lain: (1) faktor dari luar, yaitu lingkungan (alami dan sosial), serta instrumental (kurikulum, program, guru, sarana dan fasilitas); dan (2) faktor dari dalam, yaitu fisiologi (bakat, minat, kecerdasan, motivasi, dan kemampuan kognitif). Adapun faktor lain yang mempengaruhi proses dan hasil belajar siswa yaitu faktor keterbatasan waktu dan jumlah siswa yang banyak, sehingga guru menghadapi kesulitan untuk mengoreksi hasil pekerjaan siswa satu-persatu (Nadjib, 2014). Dari beberapa faktor tersebut, bahwa kemampuan pemahaman dan menyelesaikan soal materi segiempat siswa masih melakukan kekeliruan, sehingga dapat dinyatakan bahwa kemampuan siswa dalam menyelsaikan permasalahan matematis khususnya pada materi segiempat masih digolongakan rendah menuju sedang.

Dibuktikan dari hasil penelitian Bernard, et. al (2018) yang menunjukkan bahwa pemahaman dan penyelesaian masalah dalam materi segiempat pada siswa SMP masih tergolong rendah, dan masih banyak siswa yang mengalami kesulitan dalam menyelesaikan persoalan segiempat. Kesulitan yang siswa alami antara lain: (1) siswa kurang menguasai operasi bilangan perkalian; (2) siswa tidak bisa mendeskripsikan gambar yang dikaitkan dengan pengerjaan model matematika; (3) siswa belum bisa menempatkan rumus yang tepat; dan (4) siswa belum bisa memaknai gambar segiempat tersebut. Selain itu, hasil penelitian Takdimir (Nadjib, 2014) menyatakan bahwa tingkat pemahaman siswa terhadap konsep bangun datar segiempat berada dalam kategori sedang dengan skor 5,63 dari skor ideal 18 dengan standar deviasi 3,16 . Sedangkan tingkat pemahaman siswa terhadap prinsif bangun datar segiempat berada dalam kategori rendah dengan skor 5,50 dari skor ideal 26 dengan standar deviasi 3,50. Dari kedua penelitian tersebut dapat dikatakan kemampuan siswa dalam memahami dan menyelesaikan persoalan segiempat masih pada rentang rendah menuju sedang, sehingga dalam menyelesaikan persoalan materi segiempat siswa masih melakukan kesalahan. Hasil dari penelitian tersebut, dapat dikategorikan kesulitan siswa yaitu; pemahaman konsep, merumuskan perencanaan perhitungan dan melaksanakan rencana perhitungannya. Menurut Cooney et.al (1983) kesulitan siswa yaitu: (1) kesulitan dalam mempelajari konsep; (2) kesulitan dalam menerapkan prinsip; (3) kesulitan dalam menyelesaikan masalah verbal atau soal cerita, dari berbagai kesulitan dan kesalahan yang siswa alami. Oleh karena itu diperlukan adanya analisis dan solusi dari permasalahan tersebut.

Penelitian ini dilakukan untuk menganalisis dan mendeskripsikan kesalahan siswa saat menjawab persoalan materi segiempat, serta mengetahui tingkat kemampuan siswa dalam memahami dan meyelesaikan persoalan matematika pada materi segiempat pada siswa kelas VIII, sehingga muncul solusi untuk mengurangi tingkat kesalahan siswa saat menjawab soal. Menurut Sholekah, Anggreini \& Waluyo (2017) bahwa kesulitan siswa dalam menyelesaikan persoalan materi segiempat perlu adanya perhatian dan solusi untuk mengatasi kesulitan belajar supaya prestasi belajar matematika siswa dapat meningkat. 


\section{METODE PENELITIAN}

Metode penelitian yang digunakan adalah penelitian deskriptif kualitatif, yaitu penelitian yang memaparkan suatu hal, kejadian-kejadian dan menggambarkan sebuah situasi dari kata-kata, simbol, tabel dan gambar. Pendekatan yang digunakan pada penelitian ini yaitu pendekatan kualitatif. Penelitian ini dikatakan kualitatif karena berusaha mengungkapkan keseluruhan gejala yang timbul dengan menggunakan peneliti sebagai instrumen dan terjun langsung dalam penelitian. Subjek penelitian ini adalah siswa kelas VIII SMP IT Budi Luhur kota Cimahi sebanyak 17 orang. Pemilihan subjek penelitian ini berdasarkan pertimbangan dengan guru mata pelajaran dimana kemampuan siswa sangatlah bervariasi dan hasil pertimbangan bahwa harus memilih subjek yang sudah pernah mempelajari materi segiempat.

Prosedur yang dilakukan dalam penelitian ini yaitu: (1) tahap persiapan, pada tahap ini peneliti mempersiapkan instrumen tes yang sudah diuji validitasnya, menentukan subjek dan permohonan ijin kepada pihak sekolah terkait; (2) tahap pelaksanaan, pada tahap ini yaitu melaksanakan penelitian dengan melaksanakan uji tes dan melaksanakan wawancara kepada siswa; (3) tahap evaluasi, pada tahap evaluasi peneliti menganalisis hasil jawaban siswa, mengolah dan menyimpulkan data yang diperoleh.

Teknik pengumpulan data pada penelitian ini yaitu dengan memberikan tes soal uraian sebanyak empat soal dan wawancara langsung dengan siswa. Wawancara dilakukan untuk mengetahui jawaban siswa secara lebih jelas dan mendalam. Subjek wawancara yaitu tiga orang siswa yang memiliki kemampuan yang berbeda, mulai dari rendah, sedang dan tinggi, sehingga mencakup semua level. Adapun indikator pedoman penskoran instrumen tes dapat dilihat pada Tabel 1.

Tabel 1.

Pedoman penskoran instrumen

\begin{tabular}{|c|c|c|}
\hline No & Indikator & Skor \\
\hline 1 & Tidak ada jawaban & 0 \\
\hline 2 & $\begin{array}{l}\text { Memberi jawaban dengan alur perencanaan atau cara yang } \\
\text { kurang sesuai dan hasilnya salah }\end{array}$ & 4 \\
\hline 3 & $\begin{array}{l}\text { Memberi jawaban dengan alur perencanaan atau cara yang } \\
\text { kurang sesuai dan hasilnya benar }\end{array}$ & 5 \\
\hline 4 & $\begin{array}{l}\text { Memberi jawaban dengan alur perencanaan atau cara yang } \\
\text { sesuai tetapi hasilnya salah }\end{array}$ & 6 \\
\hline 5 & $\begin{array}{l}\text { Memberikan jawaban dengan perencanaan yang sesuai dan } \\
\text { hasilnya benar }\end{array}$ & 6 \\
\hline
\end{tabular}

\section{HASIL DAN PEMBAHASAN}

Instrumen yang digunakan dalam penelitian ini yaitu instrumen tes uraian sebanyak empat soal yang sudah diujikan dan divalidasi. Hasil uji validitas dari instrumen disajikan pada Tabel 2.

Tabel 2.

Hasil perhitungan validitas

\begin{tabular}{ccc}
\hline Butir soal & Rxy & Interpretasi \\
\hline 1 & 0,71 & Tinggi \\
2 & 0,31 & Rendah \\
3 & 0,52 & Sedang \\
4 & 0,73 & Tinggi \\
\hline
\end{tabular}

Sumber: Nuryana. D (2019)

Berdasarkan Tabel 2 hasil perhitungan validitas yang dihitung menggunakan Microsoft Office Excel 2010 menunjukkan bahwa kualitas instrumen tes yang digunakan dalam penelitian ini yaitu tinggi dan sedang, dengan terlebih dahulu memperbaiki butir soal nomor 2 yang berkategori rendah. Setelah itu keempat soal diteskan kepada subjek yang diteliti serta memastikan objek penelitian sudah mempelajari materi segiempat. Hasil tes tersebut dapat kita lihat pada Tabel 3. 
Tabel 3.

Data nilai kesalahan siswa berdasarkan KKM

\begin{tabular}{cccccc}
\hline $\begin{array}{c}\text { Butir } \\
\text { soal }\end{array}$ & $\begin{array}{c}\text { Nilai SMI/Butir } \\
\text { soal }\end{array}$ & $\begin{array}{c}\text { Nilai KKM } \\
\mathbf{7 5 \%}\end{array}$ & $\begin{array}{c}\text { Siswa yang } \\
\text { mendapat nilai } \\
\mathbf{2} \text { KKM }\end{array}$ & $\mathbf{2}$ KKM & < KKM \\
\hline 1 & 10 & 7.5 & 10 & $71 \%$ & $29 \%$ \\
2 & 8 & 6.0 & 2 & $14.3 \%$ & $85.7 \%$ \\
3 & 10 & 7.5 & 2 & $14.3 \%$ & $85.7 \%$ \\
4 & 10 & 7.5 & 3 & $21.5 \%$ & $78.5 \%$ \\
\hline
\end{tabular}

Berdasarkan pada Tabel 3 di atas, menunjukkan bahwa persentase siswa yang menjawab benar lebih rendah dibandingkan dengan persentase siswa menjawab salah. Ini menunjukkan bahwa kemampuan siswa dalam menyelesaikan permasalahan pada materi segiempat masih tergolong sangat rendah, yang ditujukan pada Tabel 3 bahwa tingkat kesulitan siswa dalam menyelesaikan soal dapat dilihat dari benar tidaknya cara dan jawaban. Kesalahan pada jawaban siswa pada butir soal yaitu: nomor satu 29\%; nomor dua 85,7\%; nomor tiga 85,7\%; dan nomor empat 78,5\%. Kesalahan siswa dalam menjawab permasalahan sangatlah bervariatif, mulai dari menuliskan informasi dalam memahami masalah kurang jelas, cara mengoperasikan, salah menuliskan informasi, salah saat mengambil kesimpulan, dan siswa tidak memeriksa kembali jawabannya, sehingga jawab yang siswa tuliskan keliru. Menurut Polya (Fitriani, 2016) agar siswa dapat menyelesaikan persoalan matematika, khususnya pada materi segiempat siswa haruslah memahami langkah penyelesaiannya, diantaranya: (1) siswa harus memahami masalah terlebih dahulu; (2) menyusun rencana penyelesaian masalah, pada tahap ini diharapkan siswa mampu menggunakan aturan penyusunan rencana; (3) menyelesaikan rencana masalah, pada tahap ini siswa sudah siap melakukan penghitungan dengan berbagai macam konsep; dan (4) melihat kembali jawaban, pada tahap ini siswa diharapkan mengecek kembali jawabannya dengan maksud memastikan jawaban betul atau tidak. Dari hasil analisis jawaban siswa, banyak siswa tidak melakukan penyelesaian persoalan seperti langkah yang dikemukakan Polya. Sehingga siswa mengalami kesulitan dalam menyelesaikan persoalan tersebut. Supaya lebih jelas inilah gambaran deskiptif dari kesalahan jawaban siswa pada setiap butir soal.

\section{Analisis jawaban soal nomor 1}

\section{Permasalahan:}

Pak Burhan memiliki sebidang tanah yang berbentuk persegi dengan panjang sisi $10 \mathrm{~m}$. Pak Burhan berniat ingin membuat tambak ikan mas di tanah tersebut dengan ukuran panjang $8 \mathrm{~m}$ dan lebar $4 \mathrm{~m}$. Sekeliling tambak ikan rencananya akan ditanami rumput. Pak Burhan ingin mengetahui berapa luas yang ditanami rumput.

a) Cukupkah data yang sudah ada untuk menentukan luas tanah yang ditanami rumput?

b) Bagaimana cara untuk menentukan luas tanah yang ditanami rumput? Jawaban siswa:



Gambar 1. Kesalahan jawaban siswa pada nomor 1

Berdasarkan soal nomor 1 di atas, siswa diminta untuk menentukan luas tanah yang ditanami rumput, dengan menentukan terlebih dahulu luas tanah yang berbentuk persegi dengan ukuran $10 \mathrm{~m}$, 
ukuran tambak ikan yang berbentuk persegi panjang dengan ukuran $8 \mathrm{~m} \times 4 \mathrm{~m}$. Setelah kedua luas tanah tersebut diketahui, maka luas tanah yang berbentuk persegi dikurangi luas tambak ikan dan hasilnya luas tanah yang akan ditanami rumput. Setelah itu, mari kita lihat Gambar 1, jawaban siswa nomor satu menunjukkan bahwa siswa sudah mengetahui konsep luas dari persegi dan persegi panjang. Hal ini terlihat dari jawaban siswa yaitu mengkalikan setiap sisinya untuk ukuran luas tanah yang berbentuk persegi, serta mengkalikan panjang dan lebar yang dimiliki oleh tambak ikan. Pada tahap ini siswa sudah benar, setelah kedua luasnya diketahui operasi selanjutnya luas tanah yang berbentuk persegi dikurangkan dengan luas tambak ikan dan hasilnya luas tanah yang akan ditanami rumput seluas $68 \mathrm{~m}^{2}$. Namun pada jawaban siswa, siswa tidak menuliskan informasi apa yang diketahui dan apa yang ditanyakan sehingga bagi pembaca dan pemeriksa soal, jawaban siswa kurang lengkap dan kurang jelas, serta perlunya ada kesimpulan diakhir, sehingga jawabannya lengkap dan mudah dipahami. Selain itu ada beberapa siswa juga yang masih keliru dalam menuliskan rumus yang digunakan. Pada soal nomor satu siswa menjawab soal dengan jawaban yang kurang tepat sebesar $29 \%$, artinya kemampuan siswa dalam menjawab soal nomor satu sudah dikategorikan baik.

Tabel 2.

Deskipsi kesalahan jawaban siswa pada soal nomor 1

\begin{tabular}{lc}
\hline \multicolumn{3}{c}{ Deskripsi Kesalahan Jawaban } & Jumlah siswa \\
\hline Tidak menuliskan keterangan apa yang diketahui dan & 4 \\
ditanyakannya & 2 \\
Keliru menuliskan keterangan dari rumus yang digunakan & \\
\hline
\end{tabular}

Berdasarkan Tabel 2 di atas, dapat kita ketahui bahwa kesalahan yang sering siswa lakukan yaitu tidak menuliskan keterangan apa yang diketahui dan ditanyakan sebanyak 4 orang, dan yang melakukan kesalahan dalam menuliskan keterangan rumus yang digunakan sebanyak 2 orang. Kedua kesalahan yang siswa lakukan, mempengaruhi hasil jawaban siswa. Jika prosesnya sudah salah kemungkinan besar jawabannyapun salah. Berdasarkan hasil dari jawaban siswa, peneliti melakukan wawancara terhadap siswa mengenai jawabannya pada soal nomor satu:

Guru : Apakah soal nomor satu mudah dimengerti?

Siswa : Lumayan bu, pusing soalnya lumayan rumit

Guru : Dari soal nomor satu, informasi apa yang dapat kalian ketahui?

Siswa: Luas tanah dan luas tambak ikan, dengan masing-masing memiliki ukuran yang berbeda.

Guru : Kemudian dari soal tersebut apa yang ditanyakannya?

Siswa: Luas tanah yang ditanami rumput

Guru : Berapa luasnya?

Siswa: $68 \mathrm{~m}^{2}$

Berdasarkan hasil wawancara tersebut, dapat kita ketahui bahwa siswa sudah memahami persoalan dengan baik, dibuktikan dengan pertanyaan yang diajukan guru, siswapun bisa menjawabnya dengan baik. Namun jika dibandingkan dengan hasil jawabannya di atas, terlihat siswa mampu menyebutkan secara lisan namun mengalami kesulitan saat menuliskannya. Sehingga hasil dari jawaban siswa kurang tepat.

\section{Analisis jawaban soal nomor 2}

Permasalahan:

Hitunglah keliling trapesium $A B C D$ sama kaki yang memiliki panjang sisi yang sejajar masing-masing $7 \mathrm{~cm}$ dan $19 \mathrm{~cm}$ serta tingginya $8 \mathrm{~cm}$. 
Jawaban Siswa:



Gambar 2. Kesalahan Siswa pada soal nomor 2

Pada soal nomor 2 siswa diminta untuk menghitung keliling sebuah trapesium sama kaki yang diketahui sisi sejajarnya dan ukuran tingginya. Langkah pengerjaan soal tersebut dengan menuliskan terlebih dahulu informasi yang terdapat pada trapesium sama kaki tersebut, kemudian mencari sisi yang lainnya dengan menghitungnya menggunakan persamaan Phytagoras. Setelah semua sisi diketahui, baru semua sisi dijumlahkan dan ketemulah ukuran keliling trapesium sama kaki tersebut. Pada jawaban siswa dalam Gambar 2 tersebut, siswa sudah memahami permasalahan yang ditanyakan pada soal tersebut. Siswa mulai mengerjakan dari menuliskan setiap sisi yang diketahui dan mencari sisi yang belum diketahui dengan menjumlahkan setiap sisinya sesuai dengan rumus keliling trapesium. Namun jawaban siswa masih kurang tepat karena siswa mengalami kesalahan pada penentuan sisi yang menggunakan rumus Phytagoras dengan menghitung bahwa dengan menggunakan Phytagoras itu sama dengan kelipatannya kemudian dijumlahkan. Disini pemahaman konsep/mengaitkan keliling dengan konsep Phytagoras pada segitiga siswa masih kurang, sehingga jawaban yang diharapkan kurang tepat dan perlu diperbaiki kembali. Berdasarkan hasil analisis pada jawaban siswa pada nomor dua, 14,3\% siswa yang menjawab benar. Hal ini menunjukkan bahwa banyak siswa yang kurang memahami konsep yang dimaksudkan pada soal nomor 2 .

Tabel 3.

Deskripsi kesalahan jawaban siswa pada soal nomor 2

\begin{tabular}{lc}
\hline \multicolumn{1}{c}{ Deskripsi Kesalahan Jawaban } & Jumlah siswa \\
\hline $\begin{array}{l}\text { Siswa keliru dalam menentukan nilai sisi miring dengan } \\
\text { rumus Phytagoras }\end{array}$ & 2 \\
$\begin{array}{l}\text { Siswa salah menentukan panjang dari sisi-sisi yang dimiliki } \\
\text { trapesium sama kaki }\end{array}$ & 2 \\
$\begin{array}{l}\text { Siswa tidak menuliskan yang diketahui dari trapesium } \\
\text { terlebih dahulu untuk menghitung kelilingnya }\end{array}$ & 7 \\
\hline
\end{tabular}

Deskripsi kesalahan jawaban siswa pada soal nomor 2 disajikan pada Tabel 3. Kesalahan yang siswa alami yaitu pada tahap menentukan nilai sisi miring dengan menggunakan rumus Phytagoras sebanyak dua orang, salah dalam menentukan panjang pada sisi-sisi trapesium sebanyak dua orang dan tidak menuliskan informasi yang diketahui dan yang ditanyakan pada soal sebanyak 7 orang. Kesalahan-kesalahan yang disebutkan pada Tabel 3 di atas, kesalahan yang cukup sering dilakukan oleh siswa, yang disebabkan kerena siswa lebih fokus untuk menyelesaikan dan hasil persoalan tanpa menuliskan proses penyelesaiannya dan pemahaman konsepnya rendah. Selain menganalisis hasil dari jawaban siswa, penelitipun melakukan wawancara kepada siswa untuk mengklarifikasi hasil jawabannya.

Guru : Apakah soal nomor dua tergolong mudah atau sukar?

Siswa: Sukar bu, saya tidak mengerti

Guru : Dari soal tersebut apa yang ditanyakannya? 
Siswa: Keliling trapesium bu

Guru : Nah, kalo keliling trapesium bagaimana caranya?

Siswa: Semua sisinya dijumlahkan bu, tapi saya tidak bisa mencari sisi miringnya bu.

Guru : Coba tentukan dulu sisi panjang yang sejajar kemudian gunakan rumus Phytagoras

Siswa : Saya gak mengerti bu

Berdasarkan hasil dari wawancara dengan siswa mengenai soal nomor 2, menurut siswa soal tersebut sulit. Siswa mengetahui apa maksud yang ditanyakan soal tersebut, sudah paham mengenai konsep keliling dengan menjumlahkan semua sisi-sisinya, namun siswa mengalami kesulitan saat menentukan sisi-sisi yang lainnya. Siswa diberikan solusi mencari sisi miring yang lainnya dengan menggunakan rumus phytagoras, namun siswa tidak mengerti bagaimana cara untuk menghitungnya. Maka pada hasil wawancara tersebut dapat kita simpulkan bahwa konsep dasar yang siswa miliki masih rendah.

\section{Analisis jawaban soal nomor 3}

Permasalahan:

Angga akan membuat layang-layang. Kerangka layang-layang dibuat dengan diagonal $21 \mathrm{~cm}$ dan 40 $\mathrm{cm}$. Kerangka layang-layang tersebut selanjutnya akan dilapisi kertas. Angga menyediakan kertas berukuran $80 \mathrm{~cm} \times 36 \mathrm{~cm}$ dengan harga kertas Rp. 30.000. Berapa banyak layang-layang yang dapat dibuat Angga? Tentukanlah harga kertas untuk setiap layang-layangnya? Jawaban Siswa:

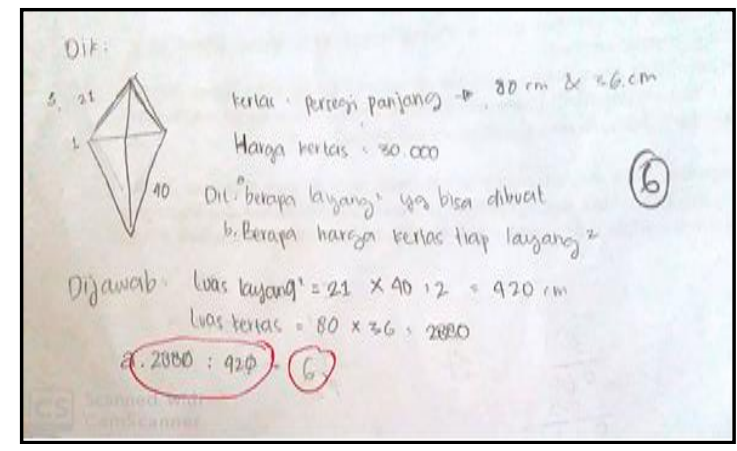

Gambar 3. Kesalahan Siswa pada soal nomor 3

Berdasarkan soal nomor 3, siswa diminta untuk menghitung berapa banyak layang-layang yang dapat dibuat dari kertas karton dan menentukan harga kertas setiap satu layangannya. Hasil dari analisis jawaban siswa pada Gambar 3, menunjukkan bahwa siswa sudah memahami permasalahan, dengan menuliskan apa yang ditanyakan dan yang diketahuinya. Kemudian siswa merencanakan perhitungan dengan menggunakan rumus luas layang-layang yang sudah diketahui setiap diagonalnya, serta menghitung luas kertas yang tersedia dengan menggunakan rumus luas persegi panjang. Namun siswa mengalami kesulitan saat membagi hasil luas kertas dengan luas layanglayang, sehingga jawaban yang siswa berikan salah, dan tidak tuntas dalam menyelesaikan soal nomor tiga tersebut. Berdasarkan hasil analisis tersebut, hanya 14,3\% yang menjawab benar, dan sisanya menjawab salah. Dari persentase tersebut, maka dapat dinyatakan bahwa kemampuan siswa dalam menyelesaikan soal nomor 3 dapat dikategorikan rendah.

Tabel 4.

Deskripsi kesalahan jawaban siswa pada soal nomor 3

\begin{tabular}{lc}
\hline \multicolumn{1}{c}{ Deskripsi Kesalahan Jawaban } & Jumlah siswa \\
\hline Siswa keliru dalam menggunakan operasi hitung & 3 \\
Siswa tidak dapat menarik kesimpulan dari jawaban & 4 \\
Siswa salah dalam membagi bilangan & 1 \\
\hline
\end{tabular}

Berdasarkan Tabel 4 bahwa deskripsi kesalahan jawaban siswa pada soal nomor 3 diketahui terdapat tiga kesalahan yang siswa lakukan, antara lain: (1) siswa keliru dalam menggunakan operasi 
hitung, sebanyak tiga orang siswa yang melakukan kesalahan; (2) siswa tidak dapat menarik kesimpulan dari jawaban, sebanyak empat orang siswa; dan (3) siswa melakukan kesalahan dalam menggunakan operasi hitung dan tidak menyelesaikan permasalahan, sebanyak satu orang. Berdasarkan hasil wawancara dengan siswa mengenai soal nomor 3 , didapatkan petikan wawancara sebagai berikut:

Guru : Dari soal nomor 3, apa yang kalian ketahui?

Siswa : Layang-layang ukuran 21 dan 45 diagonalnya, dan kertas yang bentuknya persegi panjang

Guru : Dari soal tersebut, apa yang ditanyakannya?

Siswa: Jumlah layang-layang dan berapa harga satu kertas yang bisa dibuat layang-layang

Guru : Kemudian bagaimana cara kalian mengetahui jumlah layang-layang yang ditanyakannya?

Siswa: Dengan menghitung terlebih dahulu luas layang-layang dan kertasnya

Guru : Kenapa jawabannya menuliskan 6 layangan?

Siswa: Maaf bu saya buru-buru mengerjakannya, sudah pusing bu

Berdasarkan hasil wawancara di atas, menunjukkan siswa sudah memahami persoalan yang terdapat pada soal, namun siswa sedikit teledor dan terburu-buru dalam mengerjakan soal dan tidak dicek kembali, sehingga siswa mengalami kekeliruan dalam mengerjakannya dan tidak menuliskan kesimpulan dari jawaban yang diminta soal tersebut. Sisanya kebanyakan siswa tidak mengerjakan soal pada nomor 3 , dengan alasan tidak mengerti dan waktu mengerjakan soal telah habis.

\section{Analisis jawaban soal nomor 4}

Permasalahan:

Seorang tukang bangunan akan memasang ubin berbentuk persegi dengan ukuran $20 \mathrm{~cm} \times 20 \mathrm{~cm}$ pada lantai yang berbentuk persegi panjang dengan panjang $400 \mathrm{~cm}$ dan lebarnya $300 \mathrm{~cm}$. Hitunglah berapa banyak ubin yang dibutuhkan untuk menutup lantai tersebut?

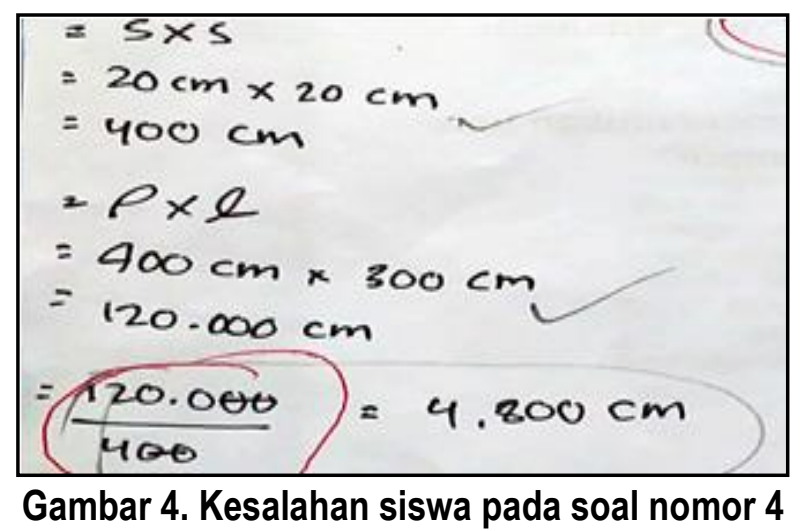

Pada soal nomor 4, siswa diminta untuk menghitung banyak ubin yang mampu menutupi lantai rumah yang berbentuk persegi panjang. Untuk menjawab permasalahan tersebut, siswa haruslah memahaminya dengan menuliskan informasi yang terdapat pada persoalan pada soal tersebut. Kemudian, menentukan luas dari ubin yang akan dipasang, dan menentukan luas lantai. Setelah itu luas lantai dibagi dengan luas ubin. Informasi ini digunakan siswa untuk mengetahui banyak ubin yang diperlukan dan mampu menarik kesimpulannya. Berdasarkan analisis pada jawaban siswa, siswa menjawab tanpa menuliskan informasi nya terlebih dahulu seperti apa yang diketahui dan apa yang ditanyakan. Siswa sudah paham dengan rumus yang digunakan sehingga bisa menentukan luas masing-masing bangun datar. Namun pada langkah terakhir saat siswa menentukan hasil pembagian dari $120.000: 400$ siswa menjawab hasilnya $4.800 \mathrm{~cm}$, dan satuan yang digunakan yaitu satuan panjang. Padahal yang ditanyakan di soal yaitu "berapa banyak ubin yang dibutuhkan" harusnya siswa menjawab 300 ubin yang diperlukan. Dilihat dari kesalahan yang terdapat pada jawaban nomor 4 ini menggambarkan bahwa siswa kurang cermat dalam membaca soal dan kurang teliti dalam mengoprasikan bilangan, sehingga jawaban akhirnya salah. 
Tabel 5.

Deskripsi kesalahan jawaban siswa pada soal nomor 4

\begin{tabular}{lc}
\hline \multicolumn{1}{c}{ Deskripsi kesalahan jawaban } & Jumlah siswa \\
\hline Siswa tidak memahami informasi yang ada & 5 \\
Siswa salah dalam menghitung bilangan dengan operasi & 1 \\
pembagian & 7 \\
Siswa tidak menuliskan apa yang diketahui dan yang ditanyakan & 7 \\
\hline
\end{tabular}

Berdasarkan Tabel 5, deskripsi kesalahan jawaban siswa pada soal nomor 4 diketahui terdapat tiga kesalahan yang siswa lakukan, antara lain: (1) siswa tidak memahami informasi yang ada sebanyak lima orang; (2) kesalahan dalam menghitung bilangan dengan opersai pembagian satu orang; (3) tidak menuliskannya informasi yang diketahui dan yang ditanyakan sebanyak tujuh orang. Kesalahan yang dilakukan siswa pada nomor 4, yaitu kesalahan yang sering dilakukan pada soal-soal sebelumnya. Sebanyak $21,5 \%$ siswa yang mampu menuntaskan dan menjawab soal dengan benar. Hal ini menunjukkan bahwa tingkat kesalahan siswa lebih besar dibandingkan dengan yang menjawab benar. Berdasarkan hasil dari jawaban siswa pada nomor 4, selanjutnya peneliti melakukan wawancara dengan siswa mengenai jawaban siswa tersebut.

Guru : Dari soal nomor 4, mengapa tidak menuliskan yang diketahui dan yang ditanyakannya?

Siswa: Maaf bu, saya terlalu fokus untuk mencari hasil yang ditanyakan. Jadi tidak sempat untuk menuliskan yang diketahui dan yang ditanyakannya

Guru : Kenapa 120000 : 400 hasilnya 4800, harusnya kan 300

Siswa: Oh iya bu, saya salah membaginya

Guru : Kenapa jawabannya tidak diperiksa kembali sebelum dikumpulkan

Siswa : Tidak bu, saya tidak memeriksanya kembali, udah pusing bu jadi pasrah aja

Berdasarkan hasil dari wawancara tersebut, dapat kita ketahui bahwa siswa sudah bisa memahami permasalahan, namun cara mengerjakannya tidak terstuktur, bahkan siswa terkesan tergesa-gesa ingin cepat selesai dan enggan untuk memeriksa jawabannya kembali dengan alasan sudah pusing. Karena sikap tergesa-gesa itulah, jawaban siswa mengalami kesalahan.

Dari keempat soal tes, soal yang paling sulit dimengerti pada soal nomor 2 yang membahas mengenai keliling trapesium. Siswa sudah mengetahui rumus dari keliling trapesium yaitu semua sisinya dijumlahkan, tetapi siswa tidak paham untuk mencari panjang sisi yang lainnya yang belum diketahui. Konsep dasar dari bangun segiempat sudah diberikan di tingkat SD dan kelas 7, namun pada kenyataannya siswa lupa konsep tersebut. Untuk 3 soal lainnya, siswa cukup paham namun lupa untuk menuliskan informasi yang diketahui dan yang ditanyakannya karena terlalu fokus pada hasil akhir jawaban. Waktu yang tersedia tidak cukup untuk dapat menyelesaikan soal dengan tuntas dan siswa mengalami kebingungan dalam mengambil kesimpulan saat jawaban akhirnya desimal.

Dari keempat soal yang dikerjakan siswa, dapat kita lihat dari hasil analisis bahwa siswa mengalami kesulitan dalam menyelesaikan soal pada nomor 2 dan 3. Pada masing-masing soal tersebut siswa menjawab dengan benar hanya $14,3 \%$. Kesalahan pada tiap soal tersebut, yaitu: (1) siswa tidak menuliskan informasi yang terdapat pada soal; (2) siswa keliru dalam menggunakan operasi hitung; dan (3) siswa tidak memberi jawaban atau solusi, serta tidak memberikan kesimpulan dari jawaban yang diberikan.

\section{KESIMPULAN}

Berdasarkan hasil analisis data di atas, dapat disimpulkan bahwa tingkat kemampuan menyelesaikan permasalahan pada materi segiempat masih dikatakan rendah. Hal ini ditunjukkan dari hasil persentase hasil analisis jawaban siswa tiap soal, bahwa tingkat kesalahan siswa pada masing-masing soal berturut-turut, $29 \%, 85,7 \%, 85,7 \%$ dan $78,5 \%$. Tingginya persentase siswa menjawab salah ditunjukkan bahwa siswa tidak memahami permasalahan yang terdapat pada soal. Hasil analisis jawaban siswa bahwa kesalahan yang sering siswa lakukan seperti: (1) tidak menuliskannya informasi persoalan seperti yang diketahui ataupun yang ditanyakan; (2) salah menuliskan keterangan saat menggunakan 
persamaan/rumus; (3) salah menggunakan operasi hitung; dan (4) tidak disertai dengan kesimpulan dari jawaban yang diberikan. Selain itu hasil dari wawancara, siswa menyatakan bahwa kesalahan yang mereka lakukan adalah kurang memahami permasalahan, lupa rumus apa yang harus digunakan, terlalu tergesagesa dan fokus kepada hasilnya sehingga informasi yang diketahui dan yang ditanyakannya tidak sempat mereka tuliskan. Kesulitan siswa dalam belajar materi segiempat terdapat pada pemahaman konsep segiempat, penanaman prinsif dan kesulitan dalam memahami permasalahan verbal/soal cerita. Kesulitan yang siswa alami menyebabkan siswa melakukan kesalahan. Solusi dari setiap kesulitan yang dialami siswa yaitu memulai pembelajaran dengan penguatan pemahaman konsep dasar, menciptakan suasana pembelajaran yang membuat siswa termotivasi untuk belajar matematika dan perbanyak latihan sehingga siswa terbiasa saat memecahkan persoalan dengan soal yang berbeda.

\section{REKOMENDASI}

Berdasarkan hasil penelitian, bahwa setiap kesalahan yang siswa lakukan tidak mutlak karena kemampuan siswa dalam menyelesaikan permasalahan, namun ada faktor lain yang mempengaruhi sehingga kesalahan itu terjadi. Dari hasil penelitian, maka peneliti merekomendasikan dalam pembelajaran matematika pada materi segiempat haruslah dimulai dari pemahaman konsep dasar, yang diketahui oleh siswa, libatkan siswa secara aktif saat proses pembelajaran, biarkan siswa yang menemukan konsepnya sendiri sehingga pembelajaran lebih bermakna dan tidak mudah dilupakan oleh siswa. Sehingga tingkat kesalahan siswa dalam menjawab soal akan berkurang. Berikanlah apresiasi kepada pekerjaan siswa, supaya muncul motivasi dalam diri siswa untuk lebih giat lagi belajar matematika.

\section{UCAPAN TERIMA KASIH}

Penulis mengucapkan terima kasih banyak kepada orang tua yang sudah mendoakan dan mendukung. Bapak Dede Nuryana, S. Pd., yang sudah membantu memvalidasi instrumen yang digunakan dalam penelitian. Bapak H. Miftahudin, S.T., sebagai kepala sekolah yang sudah memberikan ijin pelaksanaan penelitian. Bapak Dadi, S.Pd., selaku guru mata pelajaran matematika yang sudah mengijinkan dan meluangkan waktu pelajarannya bagi terlaksananya penelitian ini dan semua pihak yang sudah membantu dalam penyelesaian penulisan artikel ini.

\section{DAFTAR PUSTAKA}

Cooney, T. J., Davis, E. J., \& Henderson, K. B. (1983). Dynamics of teaching secondary school mathematics. Waveland Pr Inc.

Dwidarti, U., Mampouw, Lygia, H., \& Setyadi, D. (2019). Analisis kesulitan siswa dalam menyelesaikan soal cerita pada materi himpunan. Jurnal Pendidikan Matematika, 3(2), 315-322.

Evi, S. (2011). Pendekatan matematika realistik (PMR) untuk meningkatkan kemampuan berfikir siswa di tingkat sekolah dasar. Jurnal Penelitian Pendidikan, edisi khusus (2), 80.

Fauzi, A., Waluya, B., \& Masrukan. (2019). Pembelajaran matematika dengan pendekatan realistic mathematics education (RME) berbasis soal open-ended untuk meningkatkan komunikasi. Phenomenon, 9(1), 87-98.

Fitriani, N. (2016). Hubungan antara kemampuan pemecahan masalah matematis dengan self confidence siswa smp yang menggunakan pendekatan pendidikan matematika realistik. Jurnal Euclid, 2(2), 341-351. 
Hanifah, A. N., Sa'adah, N., \& Sasongko, A. D. (2019). Hubungan kemampuan penalaran matematis dan motivasi belajar siswa smk melalui model pembelajaran hypnoteaching. Teori dan Riset Matematika, 4(2), 121-130.

Martini, S., \& Al, E. (2018). Pengaruh pendekatan realistik terhadap kemampuan komunikasi dan self confidence siswa Smp. Jurnal Pembelajaran Matematika Inovatif, 1(2), 149-156. https://doi.org/10.22460/jpmi.v1i3.219-228

Nadjib, A. (2014). Analisis kesalahan pemahan dalam materi segiempat menutut tingkat berpikir van hiele pada siswa smp negeri suppa kabupaten pinrang. Jurnal Pepatuzdu, 8(1), 19.

Sholekah, L. M., Anggreini, D., \& Waluyo, A. (2017). Analisis kesulitan siswa dalam menyelesaikan soal matematika ditinjau dari koneksi matematis materi limit fungsi. Wacana Akademika, 1(2), 151-164, https://doi.org/10.30738/wa.v1i2.1413

Suraji, Maimunah, \& Saragih, S. (2017). karakteristik instrumen penilaian hasil belajar matematika ranah kognitif yang dikembangkan mengacu pada model pisa. Suska Journal of Mathematics Education, 3(2), 130, https://doi.org/10.24014/sjme.v3i2.3897

Widyaningrum, Zulvia, A. (2016). Analisis kesulitan siswa dalam mengerjakan soal cerita matematika materi aritmetika sosial ditinjau dari gaya belajar siswa kelas vii smp negeri 5 metro tahun pelajaran 2015/2016. Iqra, 1(2).

Yenni, \& Sukmawati, R. (2019). Analisis kemampuan berpikir reflektif matematis berdasarkan minat belajar pada mata kuliah struktur aljabar. Teorema: Teori dan Riset Matematika, 4(2), 7582.

Yuharsono. (2018). Pengembangan perangkat pembelajaran aritmetika sosial dengan pendekatan matematika realistik dan model beljar kooperatif tipe stad. Penelitian Matematika dan Pendidikan Matematika, 1(2), 92-106.

Yulia. (2019). Analisis pemahaman siswa terhadap konsep segi empat (studi kasus pada siswa kelas vii smp negri 1 sindue). IImiah Pendidikan Matematika Equals, 2(1), 24.

Zakiah, N. E., Sunaryo, Y., \& Amam, A. (2019). Implementasi pendekatan kontekstual pada model pembelajaran berbasis masalah berdasarkan langkah-langkah polya. Teorema: Teori dan Riset Matematika, 4(2), 111-120.

Zanthy, L. S. (2016). Pengaruh motivasi belajar ditinjau dari latar belakang pilihan jurusan terhadap kemampuan berpikir kritis mahasiswa di stkip siliwangi bandung. Teorema: Teori dan Riset Matematika, 1(1). 